\title{
MANAGEMENT OF INCLUSIVE EDUCATION INSTITUTIONS
}

\author{
Umi Safiul Ummah \\ Faculty of Education, State University of Malang, Indonesia \\ umiplb@gmail.com
}

\author{
Sinta Yuni Susilawati \\ Faculty of Education, State University of Malang, Indonesia \\ sinta_yi@gmail.com
}

\author{
Rizqi Fajar P \\ Faculty of Education, State University of Malang, Indonesia \\ rizqi.fajar.fip@um.ac.id \\ Dimas Arif D \\ Faculty of Education, State University of Malang, Indonesia \\ dimasarif51@gmail.com
}

\begin{abstract}
The purpose of this study is to obtain a description of the scope of management covering curriculum management, student management, facilities and infrastructure management, personnel management and education, financial management, school relationship management with the community, and special service management. This research uses qualitative approach of descriptive case study type. This research was conducted at school X in Bandung City and school Y in Sidoarjo. Data collection was done by observation, interview, and documentation study. The data were processed based on qualitative data analysis techniques according to Milles and Huberman. Based on the results of research indicate that the curriculum used in both schools are differences. School $\mathrm{X}$ in the city of Bandung prepares the curriculum before the new school year, which organizes the team at school. While school Y in Sidoarjo has no preparation of curriculum for Students with Special Needs (Anak Berkebutuhan Khusus / ABK), only compile the program composed by shadow teacher (Guru Pendamping Khusus / GPK). Management of learners, school X in the Bandung city does not specify the type of ABK that is excluded in the admission of new students in school. School Y in Sidoarjo also does not have special requirements for the ABK but the acceptance of learners with regard to the ability of the GPK in teaching. The findings of field management facilities and infrastructure of both schools include learning media and school accessibility is not fully supportive, but still pursued. Field findings on the management of educators and education-administrator show that school $\mathrm{X}$ in Bandung city shows for recruitment of educators and education-administrator is usually done in July, but if needed before July, then the school opens the registration of prospective educators. To appreciate the performance of teachers and education-administrator, the school has apprecial performance. While at school Y in Sidoarjo, there is no acceptance of educators and education-administrator because there is a letter from the local office that the school should not receive educators and education-administrator. At the financial management, there are differences between both schools. The finances at school Y in Sidoarjo are pure from the parents' tuition and organized for all the needs at school, whereas in the Y Sidoarjo school all the finances for the operation of the pure school from the government called BOS, scholarships for ABK and SN scholarships so that all learners in school are free. The management of school and community relationships, the community around the school and the parents of other learners already know and understand about the ABK at school. Parents of other students do not object ABK study in the school. They think students with special needs received are not in the category of heavy ABK. The same thing also happened at Y Sidoarjo school, only the school community did not understand the school received the ABK. The services in these support units are different, the child stimulation unit space provides pre-academic services including soft motor, language and communication, perception, hard motor, concentration, memory, and vocational or life skills. While in the inclusion room provides educational services to support reading, writing and arithmetic. The above findings imply that both schools are applying inclusive values, but there are still some things that need to be improved.
\end{abstract}

Keywords: education management, inclusive

\section{INTRODUCTION}

Quality education process will produce maximum results and relevant to the development of the times. In order to realize a quality and efficient education, it is necessary to arrange and implement educational programs that can make learners study sustainably. Because with the quality of optimal education, it is expected to produce the superiority of human resources who can master the knowledge, skills and expertise in accordance with science and technology that continues to grow with the rapid progress of the age. To be able to achieve a quality education require management capable of mobilizing all educational resources.

Based on the observations of the researchers in inclusive schools both in Bandung and Sidoarjo pointed out that the implementation of many inclusive schools are still chaotic. Students with special needs can not be in the accommodation well by the school. The curriculum used for children with special needs is equated with other children without modification. School accessibility has not accommodated all needs of the learners. In addition, the regular teachers for children with special needs feel less caring so that in teaching in the classroom teachers do not consider the existence of children with special needs. Thus, all the learning materials and evaluation are equated with reguler children. As well as the community of the school environment (the parents of reguler children) are less concerned about the implementation of inclusive education in schools. From the exposure proves that the management system in inclusive school needs to be improved. Many inclusive schools are limited to receiving special needs children to go to school but do not provide services that meet the needs of children with special needs. The child follows a school-defined system, otherwise, ideally the school's inclusive implementation adapts the system to the child.

In this study, the researchers conducted research in schools of inclusive education providers in Bandung and Sidoarjo city. The relations between the two schools are both implementing inclusive education and the researchers looked at the possibility of 
variations from both schools. Based on the concept of management in education and inclusive education that inclusive education should be able to accommodate or provide services that meet the needs of children regardless of differences. Children with special needs can attend school in public schools and schools can accommodate or provide services appropriate to the needs of children. Therefore, research on the management of inclusive organizers is required.

\section{RESEARCH QUESTIONS}

Based on the background of the problem, the general problem of this research is how mplementation of school management of inclusive education in Bandung and Sidoarjo. While the specific problems are:

1. How is the school curriculum management of inclusive education in Bandung and Sidoarjo?

2. How is the school students management of the inclusive education providers in Bandung and Sidoarjo?

3. How is the management of educators and school staff of inclusive education providers in Bandung and Sidoarjo?

4. What is the management of school facilities and infrastructure for the provision of inclusive education in Bandung and Sidoarjo?

5. How is the school financial management of inclusive education providers in Bandung and Sidoarjo?

6. How is the management of school relations and school communities providing inclusive education in Bandung and Sidoarjo?

7. What is the specific school management service for inclusive education providers in Bandung and Sidoarjo?

Based on existing research problems, the general purpose of the research is to get an describtion of the management of inclusive education providers in Bandung and Sidoarjo. Specifically this research is directed to:

1. Getting describtion of the management of the school curriculum of inclusive organizers in Bandung and Sidoarjo

2. Getting describtion of the management of inclusive school students in Bandung and Sidoarjo

3. Getting describtion of the management of educators and school staff of inclusive schools in Bandung and Sidoarjo

4. Getting describtion of the management of facilities and infrastructure of inclusive schools in Bandung and Sidoarjo

5. Getting describtion of financial management at inclusive school schools in Bandung and Sidoarjo

6. Getting describtion of the management of school relationships and school communities of inclusive organizers in the city of Bandung and Sidoarjo

7. Getting describtion of the management-specific school services of inclusive organizers in Bandung and Sidoarjo city.

\section{METHODS}

The final outcome of this study is to get describtion of management in inclusive schools including curriculum management, student management, management of educators and educationadministrator, facilities and infrastructure management, financial management, school relations management with community and special service management. This research design uses qualitative approach of case study. For data collection is done by interview technique, observation and document study.

1. Research Approach

As stated by Moleong, (2005) qualitative approach is a study that intends to understand the phenomenon of what experienced by research informants holistically and by way of description in the form of words and language, in a special context that is natural and by utilizing various scientific methods. The objective of this research is to get describtion school management of inclusive organizers at a school in Bandung and Sidoarjo. While case studies are detailed studies in a background, an object, a pedestal or a specific event (Miles and Huberman, 2007).

\section{Data Collection Technique}

Techniques of collecting research data is related to the guidelines that will be used to obtain data in the field. The most important instrument in this study is the researchers themselves. As Nasution (1984) points out, that in naturalistic research there is no other choice than to make human beings or researchers themselves as the main research instrument. This implies that the major data-gathering instrument or instrument in this qualitative approach is the researcher himself.

There are three methods of collecting data as follows:

a. Observation technique

Observation is a technique or means of collecting data by way of observing the ongoing activities (Sukmadinata, 2006). To find out about the conditions of inclusive schools that can accommodate all children is done by observation. Some matters collected by observation techniques are teacher management covering the role of regular teachers in learning in inclusive classes, the role of special teachers with inclusive classes and the collaboration of special teachers and regular teachers in the implementation of inclusive schools when they are teaching in the classroom.

b. Interview Technique

Interviews are data collection techniques by communicating with data sources (Wahyudi, 2005). In conducting the interview, the interviewer does so openly and unstructurely. It is intended that the interviewer can dig deeper about the information appropriate to the research objectives. The informants interviewed in this study are the principal, special teachers, regular teachers, finance department, Human Resource Development (HRD), reguler children's parents and parents of children with special needs. From the Principal, there are some data can be got such as planning, organizing, implementing and controlling of the curriculum management, the students 
management, the management of facilities and infrastructure, Educators and education personnel, public relations with schools.

c. Document Study Technique

Document study is a technique of collecting data by collecting and analyzing documents in term of written, drawing and electronic (Sukmadinata, 2006). The data obtained from the study document is in the form of written data in curriculum, assessment results, individual programs, evaluation of student learning outcomes, and reporters learners.

\section{Processing Technique and Data Analysis}

Based on the description, the researchers conducted data analysis according to Miles and Huberman (2007) model. In the process of analyzing this research data is done by way of stages developed as follows:

a. Data reduction

Miles and Huberman (2007) stated data reduction is defined as the election process, the focus on simplification, abstraction, rough data transformation, arising from field notes. In the process of reducing this data, which less important can be discarded. Which is the summary, and the data is growing, so that the final conclusion can be drawn and verified.

b. Data display

After all the data collected, the researchers perform data display or data presentation in order to make it easier for researchers to draw conclusions. Miles and Huberman (2005) state that the presentation of data is to present a set of organized information that gives the possibility of conclusions and taking action. Presentation of data shown is from interviews, observation and document studies.

c. Verification

The data obtained from the originally sought relationship with things that often arise and then searched the theme and taken the conclusion. The conclusion is actually still vague, but with the increasing of the data then the conclusion must always be verified during the study took place. Suprayogo and Tabrani (Wahyudi, 2005) state that verification is a formulation from the beginning to the end of a research activity to deal with the conclusions loosely, remain open and skeptical, in order to achieve a final capability.

\section{RESULTS AND DISCUSSION}

The following is the essence of interviews with principals, teachers and pedagogues about the curriculum used in schools.

\section{School $\mathbf{X}$ in Bandung City}

At school in Bandung city, school X, curriculum development team (principal, pedagogist, teacher, teacher assistant, shadow teacher) plan curriculum preparation done before new school year to modify curriculum. The curriculum for the new school year in July is already under preparation. The curriculum is prepared after the assessment, therefore the school has assessed the learners for the new school year (2011/2012) and began to prepare the curriculum.
The curriculum is modified so that all learners in the school are accommodated by taking into account the needs of each learner. School textbook X in Bandung city is prepared by the team tailored to the theme that has been specified and SK and KD according class level.

This school uses curriculum from the education office known as KTSP. Students who are less able to follow the lessons are enriched curriculum. For Students with Special Needs (Anak Berkebutuhan Khusus / ABK) schools to adopt curriculum from special school (Sekolah Luar Biasa / SLB). Both curriculum are modified and organized according to the learners' needs which are known from the assessment results. If the curriculum has been modified and adjusted to the needs of learners but learners are still difficulty in following the program that has been prepared, then the standard of competence and basic competence derived according to the needs of learners. If the learner still has difficulties, then the teaching is done based on the individualized program (PPI).

When compiling curriculum, the school $\mathrm{X}$ in Bandung consider the needs of diverse learners. The curriculum is prepared based on the results of the assessments conducted by the team at the school. The result of the assessment is the result of academic and pre-academic assessment. Once the assessment results are identified the next step is to develop a program for learners tailored to the results of the assessment and the modified curriculum. The program is structured for the long and short term. If in the long term all can be implemented before 1 year, then held re-assessment per semester to rearrange the programs to be implemented.

After the results of the assessment of students are identified and have been prepared for long-term and short-term learning, then the next step is to arrange programs categorized for semester program and weekly program called the unit plan and lesson plan. Unit plan is designed for 1 semester, while lesson plan per week. The learning in this school is thematic from grade one to sixth grade, so the theme determination is done after curriculum preparation tailored to the needs of learners.

When teaching in the classroom, the classroom teacher's job is to organize everything in the classroom starting from making the administration ie preparing the lesson plan, unit plan and preparing all the media to be used in teaching. The classroom teachers only teach maths and Indonesian, for other subjects are taught by teachers of study. The job of assistant $\mathrm{I}$ is to assist the teacher in organizing the classroom administration and to condition the learners, usually assistant I to help the gray students. If the teacher does not teach, then the 1st assistant who teaches replaces the teacher. The task of assistant II is more to help the students with special needs.

In school $\mathrm{X}$, evaluating the curriculum is done every three weeks conducted by the teacher, if there are students who are difficult then the program of individual learners can be changed according to the ability of learners. In school X in Bandung, every day teachers communicate to parents in communication book for parents, communication book for $\mathrm{ABK}$ consists of communication book in class (notes for in 
class), communication book for in class written by class teacher and distributed to students, as well as a communication book for the stimulation room filled with pedagogist and distributed to learners.

For the learning outcomes of learners in each semester there are report cards for all learners, report cards ABK shaped narrative while other students in the form of exposition. Teachers do not specify average grade in class. To know the curriculum program has been running or not, pedagogist and headmaster SD X in Bandung city toured to the classes to control and see every day for 5 minutes. Is the program that has been prepared has been running well or not at all. Principals and pedagogist sometimes conduct evaluations by following classroom lessons for 1 hour of learning.

\section{School $Y$ in East Java}

At the school Y in Sidoarjo, the GPK do not devise a special curriculum for $\mathrm{ABK}$, only adopting it from a simplified curriculum of indicators and learning objectives. School books for all learners have been obtained from government assistance and the book has been adapted to the classroom level and used by students for free. The curriculum used is the Education Unit Level Curriculum (KTSP). The learning program is based on the needs of the learners. For example, 3rd graders but have the same skills as the 2 nd grade students, the curriculum used is the 2nd class curriculum. Just like the one done by the school $\mathrm{X}$ in Bandung city.

At school $\mathrm{Y}$ in Sidoarjo, the assessment is done only at the time of registration, after which the learning program is arranged according to the needs of the students. Preparation of learning programs is only for academic material. There is no intervention related to activities outside of learning as done in school X city of Bandung (pre academic material). Programs arranged in school $\mathrm{Y}$ have long-term program objectives and there are short-term goal programs.

Preparation of the program in school $\mathrm{Y}$ by looking at the simplified annual program (program tahunan) into a semester program (program semester) from the semester program simplified into a syllabus. That syllabus is organized into a program for learners. The program can be an individual program and can also be a class program by lowering learning objectives depending on the ability of learners. Thematic lessons are conducted only in low classes whose learning adapts to the applicable curriculum and books obtained from the government. While for the high class of three to six classes of learning is not thematic.

The teacher who teach in the classroom are only one, thus the teacher prepares herself about classroom management even though there are classes in $\mathrm{ABK}$. If there is a class teacher who does not enter, then be replaced by another class teacher. Schools do not provide companion teachers, if there is a needy ABK then handed over to parents. The party responsible for $\mathrm{ABK}$ is the GPK. GPK in this school is only 2 people while the total number of ABK 16 students, from grade I to VI. Occasional GPK controls $\mathrm{ABK}$ while attending learning in class. If a $\mathrm{ABK}$ is considered capable of taking classes in class, evaluation will be done in the classroom. ABK does the classroom teacher by sitting in front with the teacher, or sometimes working in the inclusion room (depending on the circumstances and the ability of the learners). The evaluation question is read and explained by the classroom teacher. There is no difference in the evaluation between the $A B K$ that follows the classroom evaluation with reguler learners, only the number of differentiating questions. For example, for learners the number of questions 25 , for the $\mathrm{ABK}$ only 15 . But if learners can not follow the learning in the classroom, then the evaluation is done in the inclusion room by modifying the evaluation tailored to the program that has been prepared. The teachers in this school are classroom teachers who teach all subjects except English, religion, Javanese and sports. In schools there are also subject teachers who are in charge of assisting classroom teachers if they have difficulty in teaching or operationalizing learning media.

To evaluate the curriculum in school $\mathrm{Y}$ by looking at the programs that have been prepared. Each meeting has been determined learning objectives to be achieved and each meeting is written ability of learners. From this, the evaluation process is done, if there are not in accordance with learners, then the program is evaluated and then compiled again tailored to the ability of learners. There is no special communication book between school and parents. Whenever a parent wants to know his son's ability at school can consult with the principal, GPK and classroom teachers. If something happens to learners at school, then the school will communicate to the parents via phone or letter sent through the students concerned.

GPK is more aware of progress reports of students with special needs or who are often called $\mathrm{ABK}$. The assessment report for $\mathrm{ABK}$ is narrative so that it can be explained the purpose of the value. If the $\mathrm{ABK}$ is able to follow in accordance with the level of the class then the ABK follow KKM in the class that has been determined by the classroom teacher. But if not able to follow the program in the class then that make up the KKM is GPK. To find out what programs have been well run or not, GPK controls students and programs that have been developed for learners by going around the classes every day.

\section{Conclusion}

\section{CONCLUSIONS AND RECOMMENDATIONS}

The study produced seven main findings in each school including:

a. Management of Curriculum

There is an equation between the curriculum used in both schools that are using the curriculum of the service or known as KTSP. To provide educational services in schools tailored to the needs of learners, the two schools develop programs based on the assessment. The program has long and short term objectives. Each program is prepared, evaluated to be known to the development of learners. In addition there are also differences in the curriculum management of school $\mathrm{X}$ in Bandung city preparing the curriculum 
before the new school year by enriching the curriculum of the SLB and the team in the school consisting of principals, classroom teachers, teachers of study, and pedagogist. While in the school Y Sidoarjo no special curriculum preparation for the ABK only prepare a program tailored to learners with only attention to the SD curriculum and who arrange only GPK. To arrange the program by compiling the indicator of learning by looking at SK and KD in accordance with the ability of learners. The curriculum used in inclusive schools should be tailored to the adjustments made by the school to the needs of each learner. There is also an evaluation of the curriculum to know the ability of the learners.

\section{b. Student Management}

School $X$ in Bandung does not specify the type of $\mathrm{ABK}$ that is excluded in the admission of new students at school. School Y in Sidoarjo also does not have special requirements for the $\mathrm{ABK}$ but the acceptance of learners with regard to the ability of the GPK in teaching. After students are declared accepted at school, both schools informed that learners experience obstacles then suggested to psychologist and pediatrician in school $\mathrm{X}$ in Bandung city. While the school Y in Sidoarjo advised to two psychologists. After that both schools also suggested to follow additional programs at school. School $\mathrm{X}$ who used to call it with a child stimulation unit, while in school $\mathrm{Y}$ is called the inclusion room. For the placement of students in the classroom, both schools pay attention to the ability of learners, only in school $\mathrm{Y}$ has a difference, in addition to the school pay attention to the ability of learners, schools also pay attention to the ability of teachers in teaching. In a group of students, at least one school will receive 1 learner without any requirement submitted by the school. For the provision of educational services based on the results of assessments undertaken by the team at the school. For the placement of students in the classroom tailored to the ability of learners and see the ability of teachers in teaching.

\section{c. Management of Facilities and Infrastructure}

Both schools include instructional media and school accessibility are not fully supported, but attempted to support. Media learning in SD $\mathrm{X}$ in Bandung city, the media used can be from the media last year, sometimes make it suddenly before teaching. School prepares the learning media after the programming is done. Accessibility of schools is also not fully inclusive, there are still stairs in the school environment. To go to one area with other areas there are also steps, for example from the play ground to the canteen. All these things are not much different with school Y in Sidoarjo, for the learning media is also considered not optimal but cultivated can support all the needs of learners. The media used in the school, obtained from the work of the learners' senior and from the government for media per subject except PKN lessons. While the media for $\mathrm{ABK}$ obtained from contributions of parents $\mathrm{ABK}$, the contribution itself is not determined the size of the small, the contribution in accordance with the ability of parents of learners. Accessibility of schools is also not much different from school $\mathrm{X}$ in the Bandung city, school accessibility is not fully inclusive, there are still several steps from one area to another, newly built new building there are two floors, for the school location is right beside the highway. Even though every day there is a security guard who duty to take all learners. Facilities and infrastructure in schools include media and accessibility tailored to the needs of learners. For example there are learners who experience visual barriers then the school provides the media in accordance with the needs of learners.

\section{d. Management of Educators and Education Personnel}

The results showed that in school X Bandung City for recruitment of educators and education is usually done in July, but if needed before July, then the school opens registration of prospective educators. For acceptance is based on procedures that have been determined by the school. To improve performance, there is training at the beginning of the accept then attend seminars or workshops both held by schools and outside parties. Meanwhile, to appreciate the performance of teachers and educators, the school has an apprecial performance appraisal program, this is done so that the performance of all educators and educational staff increases. When it increases, the received points increase as well as the received salary increases. While in school Y in Sidoarjo there is no acceptance of educators and education staff because there is a letter from the local office that the school should not receive educators and education staf. To improve the performance of teachers and educators, there are workshop activities for regular teachers that he held by the local education office. The majority of the status of educational personnel in schools is a civil servant so that for a 2.5 year promotion every year, for a 2-year periodic automatic salary increase. If for educator who status is not civil servant, the increase salary is by looking at budget of existing fund. Teachers and educators in inclusive schools are conducted with teams such as cooperation with doctors, psychologists and others so that learners get educational services to suit their needs.

\section{e. Financial Management}

Results of research on financial management in schools there is a difference. The finances at school Y Sidoarjo are pure from the parents' tuition and organized for all the needs at school, whereas in the school $\mathrm{Y}$ in Sidoarjo all the finances for the operation of the pure school are from the government called BOS, scholarships for ABK and SN scholarships so that all learners in school are free. There is different education cost of school $\mathrm{X}$ in Bandung city between $\mathrm{ABK}$ and reguler students. The difference is because ABK follow activities in the child stimulation unit space so that learners pay more to school. As for other costs such as SPP (school fee), re-registration and extracurricular between the $\mathrm{ABK}$ and learners of the same magnitude. This is very different with the school 
$\mathrm{Y}$ in Sidoarjo where the cost of education in school for all students free of charge, it's just that the parents of ABK have the initiative to pay unspecified contributions to school. The money is used to meet the learning media for $\mathrm{ABK}$. The high cost needed in the implementation of inclusive education should the government get assistance from the government so that the burden of inclusive school fees is not too expensive so that underprivileged learners can go to school with other friends.

\section{f. Management of School and Community Relationships}

The results showed that the community around school X in Bandung city and parents of reguler learners already know and understand about the ABK at school. Parents of other students do not object ABK in the school. They think students with special needs received not in the category of heavy ABK. The same thing also happened at school $\mathrm{Y}$ in Sidoarjo. The school community does not understand the school received the $\mathrm{ABK}$. Both schools facilitate the meeting between parents' $\mathrm{ABK}$ and reguler parents. In school $\mathrm{X}$ in Bandung city called PWMG while school Y called school committee. In addition, both schools entered into cooperation with home industry. Cooperation with home industry in school $\mathrm{X}$ is done if there is a suitable subject matter, then the school hold observation to the place. While in school Y Sidoarjo, the form of cooperation with the surrounding industry, the industry provides scholarships for students who excel in every level of class at school. School relations and the surrounding community must be maintained because the community also includes school owners. Therefore, it is expected that the school environment community will give input so that the school can be more leverage to provide educational service that is friendly for all students.

\section{g. Specialized Service Management}

Field findings on special service management show that both schools provide special services, in school X in Bandung city called Child Stimulation Unit Space while in school Y called Inclusion Room. The services in these support units are different, the Child Stimulation Unit Space provides pre-academic services that include soft motor, language and communication, perception, hard motor, concentration, memory, and vocational or life skills. While in the Inclusion Room provides educational services to support reading, writing and arithmetic. To schedule learners to the school children's stimulation room in the school $\mathrm{X}$ in Bandung city by looking at the obstacles experienced. If the program is followed almost entirely, then every day learners into the child stimulation unit space. For the duration of study every 30 minute meeting. While the schedule in the school inclusion room in the school $\mathrm{Y}$ in Sidoarjo city for all $\mathrm{ABK}$ is a week 2 times learning hours with attention to the difficulty of subjects experienced by learners. For the schedule held 2 times a week that applied to all the ABK did not see the various types of obstacles that happened. A special service is a support service other than learning. This service is provided for students who experience barriers not get academic services but also nonacademic services as well. Therefore, with the existence of special services is expected the ability of learners other than academic can be further improved

\section{Recommendations}

Based on field findings, the researcher recommends to schools of inclusive education in managing schools as follows (Table 1):

Table 1

Management in School Inclusive Level of Basic Education

\begin{tabular}{|c|c|c|}
\hline No & Aspect of Management & Activity \\
\hline 1 & Curriculum Management & $\begin{array}{l}\text { - Modify the curriculum according to the needs of the learners } \\
\text { - } \\
\text { - } \\
\text { Develop an individualized learning program or program based on the assessment } \\
\text { and tailored to the needs of the learners } \\
\text { - } \text { Organize the implementation of the preparation of the teaching program in the } \\
\text { fourth semester and the lesson preparation plan } \\
\text { - Conducting evaluation so that the program is provided in accordance with the } \\
\text { needs of learners } \\
-\quad \text { Organize the type and implementation of a learning assessment } \\
-\quad \text { Organize improvement efforts and teaching enrichment } \\
-\quad \text { Make progress reports of learners }\end{array}$ \\
\hline
\end{tabular}

\section{REFERENCES}

[1] Direktorat PLB. 2009. Pedoman Penyelenggaraan Pendidikan Terpadu/Inklusi: Manajemen Sekolah (Buku 7). Jakarta: Direktorat PLB.

[2] Direktorat PLB. 2006. Manajemen Sekolah dalam Implementasi Pendidikan Inklusif. Retrieved January 2, 2017, from http://www.ditplb.or.id/profile.php?id=54.

[3] Garna. 1990. Metodelogi Penelitian Kualitatif. Bandung: Pajajaran University.
[4] Milles, M. B., \& Huberman, A.M. 1992. Analisis Dato Kualitatif. Jakarta: Indonesia University.

[5] Moleong, L. J. 2004. Metodelogi Penelitian Kualitatif. Bandung: PT Remaja Rosdakarya.

[6] Nasution, S. 1978. Petunjuk Membuat Tesis, Skripsi, Book Report, Laporan. Bandung: Jemars.

[7] Nawawi. 2010. Peran Serta Masyarakat dalam Implementasi Pendidikan Inklusif. Paper not published.

[8] Skjorten, M. D., \& Johnsen, B. H. 2003. Pendidik Kebutuhan Khusus: Sebuah Pengantar. Oslo: Unipub Forlag. 
[9] Syaodih, N. 2005. Metode Penelitian Pendidikan. Bandung: PT Remaja Rosdakarya.

[10] Tarsidi, D. 2008. Model Konseling Rehabilitasi bagi Individu Tunanetra Dewasa. Dissertation. Bandung: Indonesia University of Education.

[11] Tarsidi, D. 2008. Pendidikan Inklusif Ketika Sedikit Sumber. Retrieved January 2, 2017, from http://dtarsidi.blogspot.com/2008/06/pendidikaninklusif-rangkuman.html.

[12] Wahyudi, A. 2005. Pengantar Metodologi Penelitian. Surabaya: Unipress.

[13] Wasliman, I. 2009. Manajemen Sistem Pendidikan Kebuutuhan Khusus (Perangkat Sistem Pengajaran Modul). Bandung: Universitas Pendidikan Indonesia. 